\title{
Evaluation of the gametotoxic effect of nandrolone decanoate on the gametogenic function of male rabbit
}

\section{Evaluarea efectului gametotoxic al nandrolonului decanoat asupra funcției gametogene la iepuroi}

\author{
Pop Al. Raul ${ }^{1 *}$, Viorel Miclaus ${ }^{1}$, Simona Ciupe ${ }^{1}$, Gabriela Mutiu ${ }^{2}$, Mihai Borzan ${ }^{1}$, \\ Vasile Rus ${ }^{1}$, Horia Matei ${ }^{3}$, Ioan S. Groza ${ }^{1}$ \\ 1. University of Agricultural Sciences and Veterinary Medicine Cluj-Napoca, Faculty of Veterinary Medicine \\ 2. Faculty of Medicine and Pharmacy Oradea, Department of Histology \\ 3. University of Medicine and Pharmacy Iuliu Hatieganu Cluj-Napoca
}

\begin{abstract}
The research was conducted on a number of 24 sexually mature male rabbits of common breed, divided into two numerically equal groups. The subjects from the experimental group were given $20 \mathrm{mg} / \mathrm{kg}$ nandrolone decanoate, intramuscularly, twice a week for four consecutive weeks. The control group did not receive any treatment. At the end of the experiment the testes were harvested through bilateral orchiectomy and processed for carrying out histopathological investigations. Testicular fragments were fixated in Stieve's mixture for 24 hours, dehydrated with alcohol, clarified with butyl alcohol and included in paraffin. Serial sections of $5 \mu$ thickness were stained by Masson's trichrome method modified by Goldner. The testes taken from the control animals showed no detectable changes in optical microscopy. In the case of the animals belonging to experimental lots, there were alterations revealed evidenced by vacuolar dystrophy in the spermatocytes and spermatids, apoptosis, the edema of sperm head, spermatids syncytialization and cell necrosis followed by the disintegration of the seminal cell line with the formation of cellular debris in the seminiferous tubules lumen. These changes have affected part of the seminal cell line from the adluminal compartment (primary and secondary spermatocytes, spermatids and spermatozoids), but not those from the basal compartment (type Al and B spermatogonia), which proved to be resistant in the conditions of 30 days exposure, at a dose of $20 \mathrm{mg} / \mathrm{kg}$. In this context spermatogenesis is affected only for the period of drug action, but the risk of nandrolone decanoate transmission to humans through animal origin food consumption remains, with negative consequences on the spermatogenesis.
\end{abstract}

Keywords: gametogenesis, gametotoxicity, nandrolonone decanoat, histopatology.

\section{Rezumat}

Având în vedere faptul că hormonii steroidieni au capacitatea de a modifica atât exprimarea informației genetice codată la nivel genic cât şi nivelul fertilității la masculi, lucrarea de față şi-a propus testarea efectului nortestosteronului decanoat asupra celulelor spermatogene la iepuroi. Materialul biologic utilizat a fost repre-

*Corresponding author: Pop Al. Raul, University of Agricultural Sciences and Veterinary Medicine Cluj-Napoca, Faculty of Veterinary Medicine, 3-5 Calea Mănăştur, 400372 Cluj-Napoca, Romania, fax: +40744-695630, raulalexandrupop@yahoo.ca 
zentat de către 24 iepuroi maturi sexual, împărțiți în două loturi a câte 12 subiecți fiecare, un lot experimental la care s-a administrat intramuscular $20 \mathrm{mg} / \mathrm{kgc}$ nortestosteron decanoat, de două ori pe săptămână, timp de 4 săptămâni şi un lot martor. La sfârşitul experimentului animalele aparținând celor două loturi au fost supuse operației de orhidectomie bilaterală iar testiculele au fost fixate în amestec Stieve, incluse în parafină şi secțiuni în grosime de 5 um au fost colorate prin metoda Tricrom Goldner. Examinarea secțiunilor histologice provenite de la lotul martor a evidențiat faptul că epiteliul tubilor seminiferi prezenta aspecte normale, fără a fi semnalate leziuni, nici măcar discrete. În cazul preparatelor histologice provenite de la lotul experimental au fost consemnate o serie de modificări cu preponderență la nivelul celulelor (spermatocite primare şi secundare, spermatide şi spermatozoizi) situate în compartimentul „adluminal” al tubilor seminiferi. Severitatea şi gradul de extindere al leziunilor a variat semnificativ de la un tub seminifer la altul şi chiar de la o porțiune la alta a aceluiaşi tub seminifer. Aceste modificări au constat în apariția de celule în apoptoză precum şi numeroşi corpi apoptotici, degenerescență balonizantă a spermatocitelor şi spermatidelor, sincițializarea spermatidelor, necroze însoțite de dezorganizare zonală moderată a epiteliului seminifer. În câteva zone au fost evidențiate un număr mic de celule afectate (spermatogoniile) şi în compartimentul „bazal”. Dacă leziunile din compartimentul „adluminal” sunt reversibile, cele din compartimentul „bazal” sunt ireversibile deoarece afectează celulele „de rezervă” ale liniei spermatogenetice, compromițând într-o oarecare măsură fertilitatea mascului. Aspectele evidențiate ridică semne de întrebare asupra oprtunității utilizării nortestosteronului decanoat în terapie sau stimularea producției animale deoarece afectează funcția spermatogenetică la masculi existând totodată riscul transferului lor la om prin consumul de alimente de origine animală.

Cuvinte-cheie: gametogeneză, gametotoxicitate, nortestosteron decanoat, histopatologie.

Received: $5^{\text {th }}$ August 2012; Accepted: $3^{\text {rd }}$ May 2013; Published: $15^{\text {th }}$ June 2013.

\section{Introduction}

The spermatogenesis development in physiological conditions is dependent on hormonal and neurochemical signals transmitted through the axis of the hypothalamus, pituitary, Leydig interstitial cells, Sertoli cells and germinal epithelium (1). Any disturbing factor which intervenes on this transmission axis of neuro-hormonal signals can influence in a greater or lesser degree the spermatogenesis process' development and thus male fertility (2). Administration of hormonal substances that contain natural steroid hormones or their synthetic analogues are commonly used in the therapy of various reproduction disorders, for the purpose of sexual cycle manipulation, as well as for increasing muscle mass and improving the carcass qualities (3). Not respecting the waiting period or possible illegal treatments can determine the persistence of some residues in the edible tissues and organs from farm animals. A number of studies have drawn the attention on the adverse reactions produced by some hormonal chemicals, with direct effects on the spermatogenetic func- tion (4). Such results were reported after the administration of substances such hexestrol diacetate (5), dienestrol (6), nortestosterone decanoate (7) and estradiol benzoate (8). The studies were conducted on pubescent males belonging to several species of mammals: rats (3), mice (7), Guinea pigs (9), and rabbits (5). Most frequently, the experiments were performed on rabbits due to their convenient body size, well studied andrology characteristics and the fact that this specie is commonly used in toxicology (2) and immunohistochemical (7) studies. The most sensitive cells to the action of toxic agents are the ones found in the mitosis process or DNA synthesis, known as proliferative spermatogonia or primary preleptone spermatogonia. There are also exceptions, so that the toxic agent affects the RNA synthesis inhibitors of germ cells found in an advanced stage of differentiation. The most resistant cells to the action of toxic agents are considered to be the type B1 spermatogonia, also called the "reserve" spermatogonia (10).

Given the fact that among the hormonal substances administrated for various purposes to 


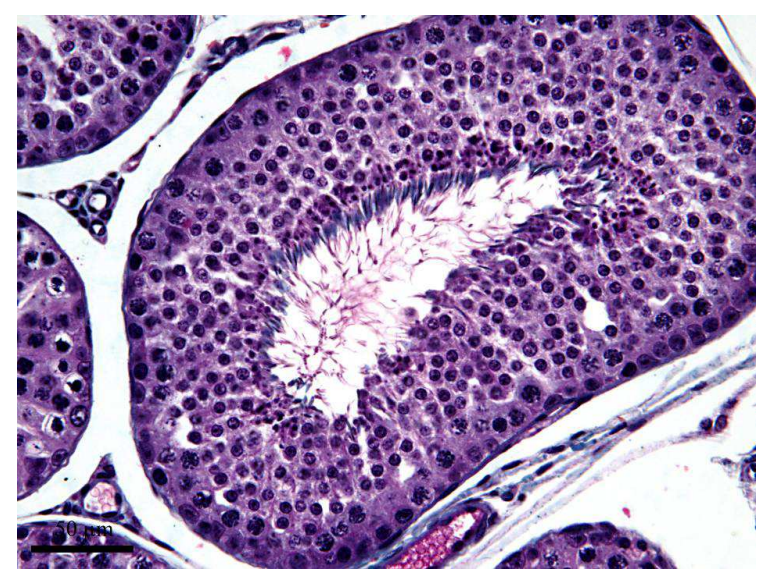

Figure 1. Physiological aspects of the gametogenesis process (Goldner's Trichrome, 40x obj.)

farm animals the nandrolone decanoate was the less studied one, the present research aims to assess the effect of this synthetic steroid on the spermatogenesis development through histological evaluation of all the spermatogenic cell line and especially spermatocytes and spermatids.

\section{Materials and method}

The biological material used in this study was represented by a number of $24 \mathrm{pu}$ bescent bucks aged between 8 and 12 months, weighing from 2300 to $3000 \mathrm{~g}$, common breed, divided into two groups, each of 12 animals: a control group and experimental group. The males belonging to the experimental groups were administrated intramuscularly nandrolone decanoate in a dose of $20 \mathrm{mg} / \mathrm{kg}$, bi-weekly for four weeks, while the second group was considered the control one. After four weeks all the rabbits underwent a bilateral orchiectomy operation, the anesthetic management consisting in the administration of a mix of xylazine hydrochloride (Narcoxyl) at a dose of $5 \mathrm{mg} / \mathrm{kc}$ and ketamine (Ketaminol) at a dose of $50 \mathrm{mg} / \mathrm{kg}$, so as to obtain the testicular tissue samples necessary for the histopathological investigations conducted in order to detect possible morphological changes induced by the action of nandro-

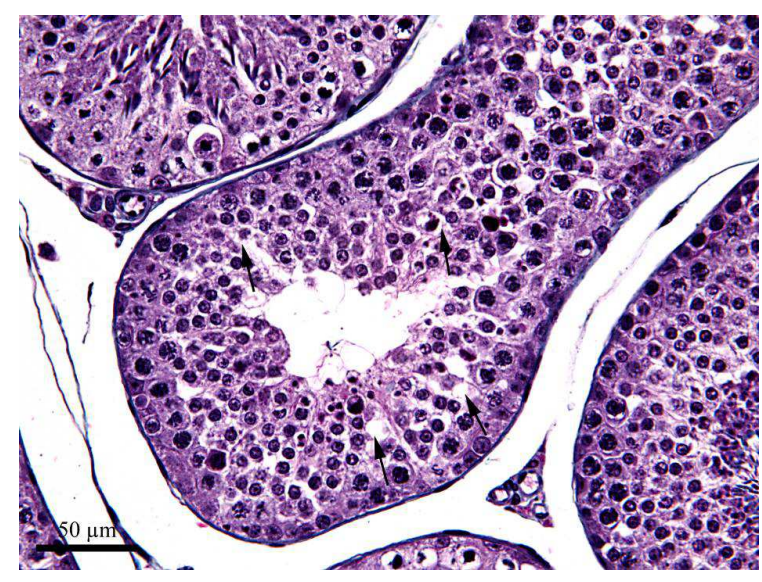

Figure 2. Vacuolar dystrophy of moderate intensity (black arows) (Goldner's Trichrome, 40x obj.)

lone decanoate on the seminal epithelium cells. In order to conduct histological investigations, testicular fragments were fixated in Stieve's mixture (glacial acetic acid $4 \mathrm{ml}$, formalin concentrated $20 \mathrm{ml}$, sublime saturated aqueous solution $76 \mathrm{ml}$ ) for 24 hours, dehydrated with alcohol, clarified with butyl alcohol (n-Butanol) and included in paraffin. Serial sections of $5 \mu \mathrm{m}$ thickness were stained by Masson's trichrome method modified by Goldner and examined using an Olimpus BX41 microscope.

\section{Results}

By microscopic examination, normal aspects of ongoing spermatogenesis process were identified in the control group (Figure 1). In the case of the experimental group a number of lesions were found in the seminiferous epithelium with damage to various types of cells belonging to the seminal line. Their intensity varied according to the cell type, and the extent of the lesions was very different from one seminiferous tube to another.

In the case of some seminiferous tubes, the changes were more subtle, revealing vacuolar degeneration in a moderate number of cells, mainly in spermatocytes (preleptotene and leptotene) and spermatids. A discrete intercellular edema as well as a moderate number of apoptotic cells and apop- 




Figure 3. Head edema of the spermatozoids (black arrows) (Goldner's Trichrome, 40x obj.)

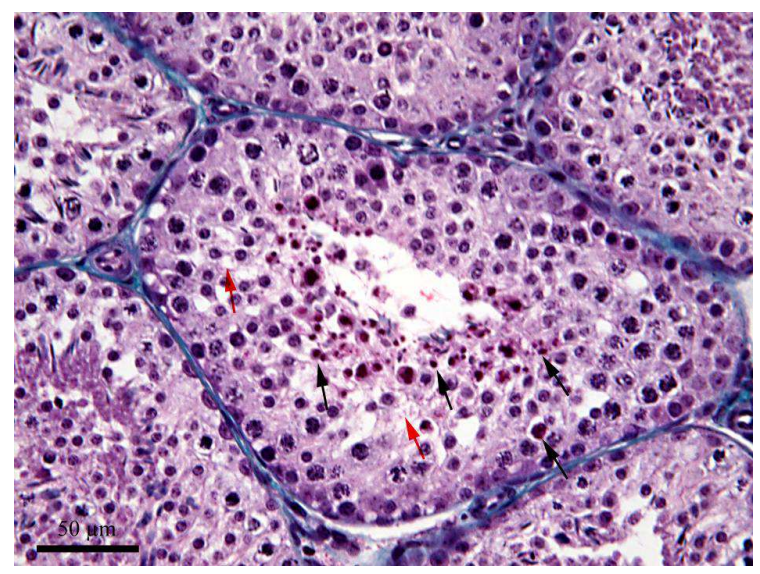

Figure 5. Aptotic spermatocytes and spermatides, apoptotic bodies (black arrows) and vacuolar dystrophy (red arrow) (Goldner's Trichrome, 40x obj.)

totic bodies especially in the adluminal compartment of the seminiferous tubes were also seen. In other tubules, the vacuolar degeneration was present in a larger number of seminal line cells (Figure 2), and the number of apoptotic bodies was obviously higher. In these tubes the spermatozoids are also affected, the majority revealing head swelling (Figure 3) and changes in the tinctorial affinity (low tinctorial affinity). Apoptosis pro-



Figure 4. Syncytial cells in apoptotis (black arrows), cell mobilisation phenomenon with the partial obliteration of the seminiferous tube lumenum (red arrow) (Goldner's Trichrome, 40x obj.)

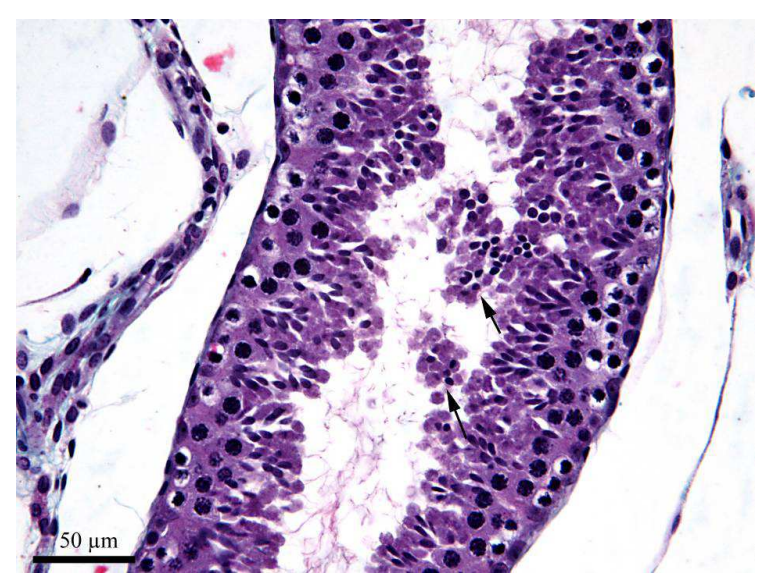

Figure 6. Spermatide groups detached from the seminiferous tubes (black arrows) (Goldner's Trichrome, 40x obj.)

cesses were present (Figure 4 and Figure 5), sometimes in the spermatocytes area, but most commonly in the spermatids, with the appearance of apoptotic bodies and separation tendency from the epithelium (Figure 6).

Only in very few tubules the vacuolar degeneration was massive and accompanied by brutal destructions which included all cell lines except for the spermatogonia, the consequence 




Figure 7. Isolated groups detached spermatides (black rarows) (col. Tricrom Goldner, 40x obj.)

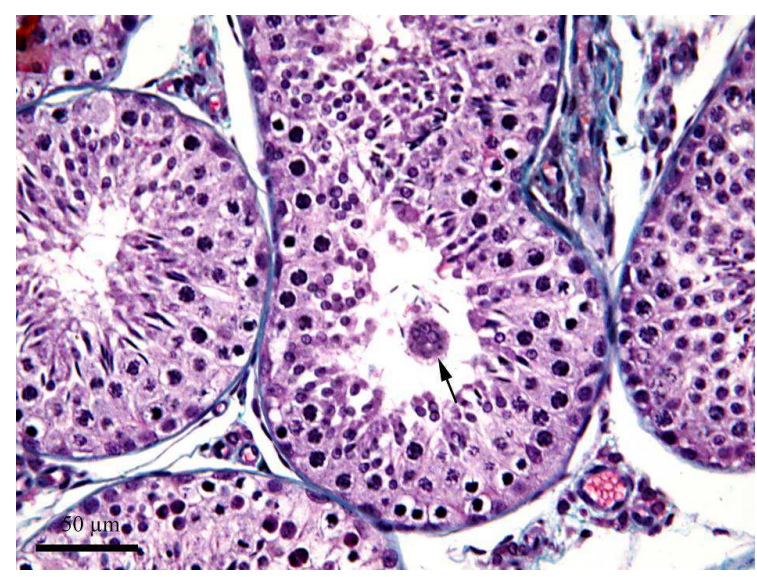

Figure 9. Spermatide syncytium in the lumen of the seminiferous tubes (black arrows) (col. Tricrom Goldner, 40x obj.)

being the detachment of the affected cells from the seminiferous epithelium, either under isolated groups of two or three spermatids or slightly larger groups, but in no case the detachments were so massive that they had the tendency to block the lumen of the seminiferous tubules (Figures 6, 7, 8, 9). In case of some tubes with pronounced alterative processes, zonal processes of spermatid syncytialization were revealed, with these syncytiums detaching from the seminiferous epithelium and joining the



Figure 8. Cell and proteic debris in the lumenum of the seminiferous tubes (black arrows) (col. Tricrom Goldner, 40x obj.)



Figure 10. Spermatozoid edema, cell debris and the syncytialization of the spermatids (black arrows) (Goldner's Trichrome, 40x obj.)

debris found in the lumen of the seminiferous tubule. The spermatids that formed these syncytiums were not equally affected, for some still preserved characteristic morphology features (Figure 9), while others showed obvious signs of degeneration (Figure 10).

\section{Discussions}

The examination of the histological smears from the male rabbits belonging to the 
experimental group, subjected to the nandrolone decanoate treatment, revealed damage mostly in the adluminal compartment cells (primary and secondary spermatocytes and spermatozoids). The lesions present at this level were diverse (cell edema, vacuolar degenerescence, the appearance of spermatid syncytia, apoptotic bodies and apoptotic cells) and had different degrees, from discrete to advanced, and on small areas even very advanced, of spermatogenesis process disruption. On the other hand, the seminal cell line from the basal compartment (spermatogonia type A1 and B), were resistant under exposure to a $20 \mathrm{mg} / \mathrm{kgc}$ nandrolone decanoate dose administrated bi-weekly for a period of 30 days. The ceasing of male rabbit exposure to nandrolone decanoate will determine the complete return of the spermatoand spermiogenesis given the fact that none of the two spermatogonia categories (A1 and B) were significantly affected, so the gametogenesis will be damaged only temporarily.

In comparison, in a previous study carried out in order to assess the gametotoxic effect of hexoestrol diacetate on gametogenic function in the same species (13), we obtained data on hexoestrol diacetate toxicity on the seminal line cells showing that it is vastly superior to that manifested when exposure to the action of nandrolone decanoate. Under these conditions detection of food residues of hexoestrol diacetate requires increased attention in order to prevent exposure of human consumers (especially pregnant women and prepubertal boys) to the action of this compound.

Because the spermatogenetic cycle duration (time necessary for a group of germinal cells to evolve from differentiated A1 spermatogonia to sperm cell stage) is of 48 days, many researchers recommend an animal exposure period to the potential toxic agent of minimum 63.6 days in male rabbits (7). The results obtained in this research show that accurate data regarding nandrolone decanoate (which we consider relevant) can be obtained in much shorter time - 30 days in our case. The dosage used in this study $(20 \mathrm{mg} / \mathrm{kg}$ nandrolone decanoate) is found in the majority of the protocols used for assessing the impact of steroid hormones and synthetic compounds on gametogenic function (2). The choice of histopathology as investigation method for nandrolone decanoate effect assessment is based on the fact that it is considered to be sensitive and specific, managing to highlight changes from discrete to advanced, in the seminiferous epithelium components.

The understanding and use of the correct and coherent terminology for the noticed changes in accordance with the degree of testicular cell damage are also important problems when reporting and interpreting the testicular histopathology $(2,7)$. The interruption of spermatogenesis may directly reflect the toxic agent's effect on the seminiferous epithelium, both Sertoli and the seminal line cells, or it might be a secondary answer to raised hormonal levels, to vascular damage, or fluid balance at a vascular or epididymal level. Regardless whether it is spontaneous or induced, the death of the seminal cell line seems to be permanent through apoptosis, a process strictly connected to the activity of Sertoli cells. The depletion of the seminal cells is the most common consequence of the spermatogenesis process disruption and is it rather a consequence of the cell death than delamination (4). A partial denaturation of the seminal cell line can be revealed or maybe the toxic agent can affect only one single type of cells (7). The vacuolar degenerescence in or between the Sertoli cells is an early sign of damage to Sertoli cells. The vacuoles can be solitary and located at different epithelium levels. In general it is possible to determine through optic microscopy if the vacuoles are intra- or extracellular. In other cases the intracellular vacuolization or the swelling can affect the basal area of the Sertoli cell cytoplasm and cause the migration and disorganization of the seminal cells (12). These changes are suggestive for Sertoli cells and can represent the damage of the smooth endoplasmic reticulum. 


\section{Conclusions}

Bi-weekly administration, of $20 \mathrm{mg} / \mathrm{kg}$ nandrolone decanoate for 30 days leads to the alteration of some seminal line cells with the emergence of the moderate apoptosis phenomenon, especially at the level of the spermatocytes and pachytene spermatids, spermatids syncytialization, cell edema and vacuolar dystrophy, accompanied by moderate cell depletion in the adluminal compartment of the seminiferous tubes. The damage of the cells from the adluminal compartment of the seminiferous tubes in rabbits exposed to the action of the nandrolone decanoate confirms the capacity of this substance to cross over the testicular hematologic barrier as well as the one formed by the Sertoli cells, a fact which determines in these conditions the partial depopulation of the seminal cell line.The problem concerning the possibility of using nandrolone decanoate in therapy or in stimulating animal production is highlighted, as well as the possible influence of this synthetic steroid compound in the development of the gametogenetic process in human species males because of the risk in transferring some substances through consumption of food of animal origin.

\section{Acknowledgements}

This work was supported by CNCSISUEFISCSU, project PN II RU-PD code 258, contract no. $181 / 2010$.

\section{References}

1. Rajesh KN. Endocrine Disruptors: Effects on Male and Female Reproductive Systems. Hardcover Jan 21. 2009; 149-153;
2. Karbalay-Doust S, Noorafshan A, Ardekani FM, Mirkhani H, Baker G. The reversibility of sperm quality after discontinuing nandrolone decanoate in adult male rats. Asian Journal of Andrology. 2007;9(2):235-9.

3. Pinelda MH, Dooley MP. McDonald's Fifth Edition, Veterinary endocrinology and reproduction. Blackwel Publishing. 2003, 432-436

4. Creasy D, Cartwright J, Moreland S, Willoughby C, Collier M, Odum J. Endocrine disruption: Aguidance document for histologic evaluation of endocrine and reproductive tests. Syngenta, 2008.2-5

5. Bjorndahl L, Mortimer D, Barratt CLR, Castilla JA, Menkveld R, Kvist U, Alvarez JG, Haugen TB. A practical guide to basic laboratory andrology. Cambridge University Press. 2010;114-116

6. Anderson D. Brinkwoth MH. Male-mediated Developmental Toxicity, 2007, RSC Publishing; 173-178

7. Lubna HT, Noor HM, Iman NH, Iman MA, Salem RY, Maher IA. Nandrolone decanoat administration to male rats induces oxidative stress, seminiferous tubules abnormalities and sperm DNA fragmentation. 2010; 165174

8. Aydilek N, Aksaka M, Karaklicik AZ. Effects of testosterone and vitamin $\mathrm{E}$ on the antioxidant system in rabbit testis. Andrologia. 2004 Sep, 277-281

9. Anderson D. Male-mediated Developmental Toxicity. Toxicol Appl Pharmacol. 2005 Sep 1;207 (2 Suppl):50613

10. Creasy, D. M. Evaluation of testicular toxicology: a synopsis and discussion of the recommendations proposed by the Society of Toxicologic Pathology. Birth Defects Res B Dev Reprod Toxicol 68, 2003. 408-415.

11. Blanco-Rodriguez J, Martinez-Garcia C, Porras A. Correlation between DNA synthesis in the second, third and fourth generations of spermatogonia and the occurrence of apoptosis in both spermatogonia and spermatocyte. Reproduction. 2003; 126 (5):661-8

12. Feldman EC, Nelson RW. Canine and feline endocrinology and reproduction. Saunders. 2004, 987-1005 13. Pop AR, Groza I, Miclaus V, Simona Ciupe, Gabriela Mutiu, Borzan M. The influence of hexoestrol diacetate on gametogene function in male rabbit. Romanian Journal of Morphology and Embryology 2011, 52(1 Suppl):413-417 